\title{
INTESTINAL PARASITE INFESTATION AND ITS RISK FACTORS: A CROSS- SECTIONAL SURVEY AMONG CHILDREN IN DUHOK CITY, KURDISTAN REGION IRAQ
}

\author{
HELAN SAMAN JAMEEL, BSC* \\ SOUZAN H EASSA, BVMS, MS, PHD**
}

\section{Submitted 15 July 2020; accepted 8 March 2021}

\begin{abstract}
Background: A cross-sectional study concerning the prevalence of intestinal parasitic infection among children in Duhok city was carried out from September 2018 to the end of October 2019.

This study aimed to show the prevalence and establish some risk factors associated with gastrointestinal parasite infection in children of both sexes in the age group ranging from $(<1$ 12) years old in Duhok city, Kurdistan Region, Iraq.

Method: A total of (1548) stool Specimens were collected and tested successively, 1310 from the Heevi Pediatric Teaching Hospital and 238 from the primary school in Duhok city. Both sexes in the age group $(<1-12)$ years old were involved. All stool specimens were examined microscopically using wet mount smear, concentrations, and Modified ZihelNeelsen stain methods.

Results: The overall prevalence of intestinal parasitic infections was $869(56.14 \%)$. Cryptosporidium spp. 709(66.08\%), Entamoeba spp. 302(28.15\%), Giardia lamblia 61(5.68\%) and Ascaris lumbricoides 1(0.09\%) were the common parasites found. Among $869(56.14 \%)$ positive specimens, intestinal parasites were detected as a single $670(77.1 \%)$, double 194(22.32\%), and triple 5(0.575\%) infection. Male children between the ages of $1-5$ years old showed the highest infection rate $280(31.81 \%)$. The prevalence of intestinal parasite infections was significantly related to gender $(p<0.05)$ and the seasons of the year during the period of study $(p<0.001)$. However, statistically significant associations between children infection with parasites and body weight and educational status of their parents were not observed. Modified Acid-Fast Stain used only for Cryptosporidium spp. detection.

Conclusion: In Heevi Pediatric Teaching Hospital, the wet mount method is the only method for detecting intestinal parasites; this can leads to missing detection of many parasites. Therefore, modified acid-fast stain and concentration methods are recommended to reach the best results. Education on personal hygiene and environmental sanitation is required to reduce the prevalence of intestinal parasites among children in Duhok.
\end{abstract}

Duhok Med J 2021; 15 (1): 81-95.

Keywords: Children, Duhok city, Intestinal parasitic infection, Risk factors.

I ntestinal Parasitic infection (IPIs) are among the most common diseases around the world. Particularly, millions of persons are infected and ill with parasitic diseases within developing nations ${ }^{1}$. Children are more exposed to intestinal parasitic diseases than adults due to their immature immune system and poor sanitation $^{2}$.
The main risk factors related to these diseases are unsuitable sanitation practices, lack of access to hygienic water, poor cleanness, and health services ${ }^{3}$ due to the low environmental condition and overpopulation ${ }^{4}$. The infestation rate with different intestinal parasites was raised since the need for treatment and the terrible hygienic situation, particularly

\footnotetext{
* Postgraduate student, Department of the Medical Microbiology, College of Medicine, University of Duhok, Kurdistan Region, Iraq.

** Assist. Professor, Department of the Anatomy, Biology, and Histology, College of Medicine, University of Duhok, Kurdistan Region, Iraq.
} 
among households with low living levels ${ }^{5}$. These risk factors provide ideal conditions for the development, transmission and increased possibility of exposure to intestinal parasites ${ }^{6}$. Moreover, it has been influenced by the used analytic techniques and the number of examined stool cases ${ }^{7}$.

Among the most significant intestinal parasites are intestinal protozoa like Entamoeba histolytica, Giardia lamblia, Cryptosporidium spp., Balantidium coli, Dientamoeba fragilis, and intestinal helminths like Ascaris lumbricoides, Trichuris trichiura, and Strongyloides stercoralis ${ }^{8}$. These infections are a sign of keen community health problems, resulting in growth retardation, iron deficiency anemia, and other physical and mental health concerns in children ${ }^{9}$.

Like in other developing nations in Iraq, intestinal parasite infections are considered major public health problems in various Iraqi provinces. Several epidemiological studies showed that disease incidence differs from area to area ${ }^{10}$.

This survey was conducted because little information is available about the prevalence of intestinal parasitic infections and their related risk factors among children in Duhok city.

\section{MATERIALS AND METHODS}

Study setting and duration

Duhok city is the main municipality and the center of Duhok governorate (Duhok is spelled as Duhok, Dohuk, or Dahuk). It is the northernmost province of Iraq. Duhok city constituency occupies 31.3 hectares of land, (43.20-44.10) Longitude and (36.4037.20) Latitude. The total population of Duhok province is approximately 1.5 million, whereas around 505,491 live in
Duhok city ${ }^{11}$. This cross-sectional study was carried out in Duhok city from September 2018 to the end of October 2019.

Samples and data collection and selection criteria

Children were only included after written consent was obtained from parents on behalf of their children. Consent forms were given to interested parents to explain the objectives and procedures. In addition, a questionnaire form was also given for socio-demographic data, environmental factors, and behavioral sanitary habits of the children. Children on anti-parasitic medications three weeks before the research were excluded.

In Heevi Laboratory, the stool specimens were collected from each inpatient and outpatient; a fresh fecal specimen was collected with their parents' aid or accompanied individual. All children were included, with or without presenting clinical symptoms. The stool specimens were collected from children ( $\leq 6$ years) in school with their parents' assistant, disposable plastic containers with a wide clean universal; dry screw caps were prelabeled with name, age, sex, and name of the school and given to parents of children. Children above six years of age were educated on the proper methods for collecting the stool Specimens.

Number of stool specimens and study size During the study period, a total number of (1548) stool Specimens were collected and tested successively, 1310 from the Heevi Pediatric Teaching hospital and 238 from primary schools in Duhok city. In order to achieve a 95\% confidence level, the minimum study size was determined using the formula $n=(Z 2 \times p(1-p)) / e 2$ where $n$ 
is the Specimen size, $\mathrm{Z}$ is the standard score of $95 \%$ confidence interval, $p$ is the prevalence (since no previous data existed, 0.5 was used) and e is the margin of error (1.96) with a significance level set at $\mathrm{P}=$ $0.05^{12}$.

\section{Examination of stool specimens}

Stool specimens were transported to the laboratory, and each stool specimen was examined macroscopically to find any abnormalities visible by the naked eye (color, consistency, presence of blood, mucus, pus, and large worms). The microscopical examination was done by direct smear and concentration techniques (Flotation and Sedimentation) for the presence of intestinal protozoa and helminths diagnostic stages. Modified Acid-Fast Stain was used for detecting the Coccidian parasites. Various methods are available for detecting parasitic intestinal infection, consisting of comprehensive techniques instructions ${ }^{13,14,15}$.

\section{Statistical analysis}

Data were entered into the Microsoft Excel program. Using the Chi-square $(\chi 2)$ test, results were evaluated and analyzed to find associations between the prevalence of intestinal parasite infections and the risk factors among infected and non-infected children. Statistical significance was set at $p<0.05$.

\section{Ethical approval}

Scientific and Ethical approvals for the study were granted by the Scientific Committee of the College of Medicine/Duhok University (Scientific \& ethical approval no. 690 on October $10^{\text {th }}$, 2018). Clearance from the General Directorate of Education in Duhok (approval no. 18064 on November $19^{\text {th }}$, 2018) was also obtained before collecting specimens from the Heevi Pediatric Hospital. Selected several primary schools received a formal request from the College of Medicine, then children's parents and/or guardians were contacted to outline the study's aim and clarify the study's purpose.

\section{RESULTS}

Prevalence of intestinal parasites

In this research, a total of (1548) stool specimens were collected and tested from different ages of both sexes. The overall prevalence of the intestinal infection among the children's stool's total examined specimens is shown in Figure (1.). A total of $868(56.07 \%)$ specimens were identified with the intestinal protozoan, and only one $1(0.06 \%)$ specimen was identified with intestinal helminths.

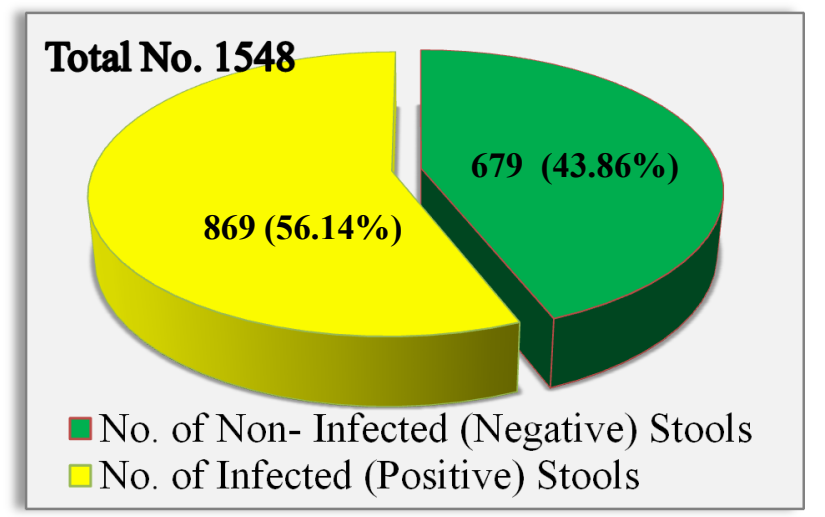

Fig. 1: Prevalence of intestinal parasite infections among the total examined children stool specimens.

Socio-demographic Variables

Out of the total examined children, $880(56.84 \%) \quad$ were males, and $668(43.15 \%)$ were females; among these, a total of $529(60.87 \%)$ males and 340 (39.13\%) females were positive. The mean age of the study participants was six years. The minimum age recorded was one day, and the maximum age was 12 years. Table 1 shows age groups together with gender factors. The rate of infection was higher in 
females than in males in age group less than one-year-old 164 (24.55\%), while the rate of infection was higher in males than in females in age group ranged (1-5) years old which was 280 (31.81\%). There was a highly significant difference between males and females at level $(p<0.001)$.

Table (1): The percentage of Intestinal Parasitic Infections concerning (Sex) and (Age groups) in Children in Duhok city.

\begin{tabular}{|c|c|c|c|c|}
\hline \multirow{2}{*}{ Age groups (Years) } & \multicolumn{2}{|c|}{ No. of examined } & \multicolumn{2}{|c|}{ No. (\%) of Infected } \\
\hline & Male & Female & Male & Female \\
\hline Less than one & 359 & 232 & $148(16.82 \%)$ & $164(24.55 \%)$ \\
\hline $1-$ Less 5 & 338 & 301 & $280(31.81 \%)$ & $101(15.12 \%)$ \\
\hline $5-12$ & 183 & 135 & $101(11.48 \%)$ & $75(11.23 \%)$ \\
\hline Total & 880 & 668 & $529(60.11 \%)$ & $340(50.90 \%)$ \\
\hline
\end{tabular}

$\chi 2=13.097, \mathrm{D} . \mathrm{F}=1, \mathrm{P}<0.001 * * *$

*** Highly Significant Difference.

Of the 869 positive stool specimens examined, $670(77.1 \%)$ children were positive for single intestinal parasites and 199 (22.895\%) children were positive for two or more intestinal parasites. Table(2) shows the intestinal parasitic species (single infection). Entamoeba spp. 107(15.97\%), Giardia lamblia 32(4.78\%), Ascaris lumbricoides 1(0.15\%), and Cryptosporidium spp. $530 \quad(79.10 \%)$. While the species of the co-infections of intestinal parasites, which were two parasites present together (double infestations): Entamoeba spp. with Giardia lamblia 20 (10.31\%), Entamoeba spp. with Cryptosporidium spp. $170(87.63 \%)$, and Giardia lamblia with Cryptosporidium spp. 4(2.06\%). While the (triple infestations) was the only combination of Entamoeba spp., Giardia lamblia, and Cryptosporidium spp. were combined 5(100\%).

Table (2): Distribution of single, double, and triple infection by the intestinal parasites among the total examined children in Duhok city

\begin{tabular}{lll}
\hline Single Infection with & No & $\%$ \\
\hline Entamoeba spp. & 107 & 15.97 \\
Giardia lamblia & 32 & 4.78 \\
Cryptosporidium spp. & 530 & 79.10 \\
Ascaris lumbricoides & 1 & 0.15 \\
\hline Total & 670 & 100 \\
Double Infection & & \\
Entamoeba spp. + Giardia lamblia & 20 & 10.31 \\
Entamoeba spp. + Cryptosporidium spp. & 170 & 87.63 \\
Giardia lamblia + Cryptosporidium spp. & 4 & 2.06 \\
\hline Total & 194 & 100 \\
Triple Infection & & \\
Entamoeba spp. + Giardia lamblia + Cryptosporidium spp. & 5 & 100 \\
\hline Total & $\mathbf{5}$ & $\mathbf{1 0 0}$ \\
\hline
\end{tabular}


Figure (2) shows the parasites' species recognized were Cryptosporidium spp.709 (66.08\%), followed by Entamoeba spp.
302 (28.15\%), Giardia lamblia 61 (5.68\%), and Ascaris lumbricoides 1 $(0.09 \%)$.

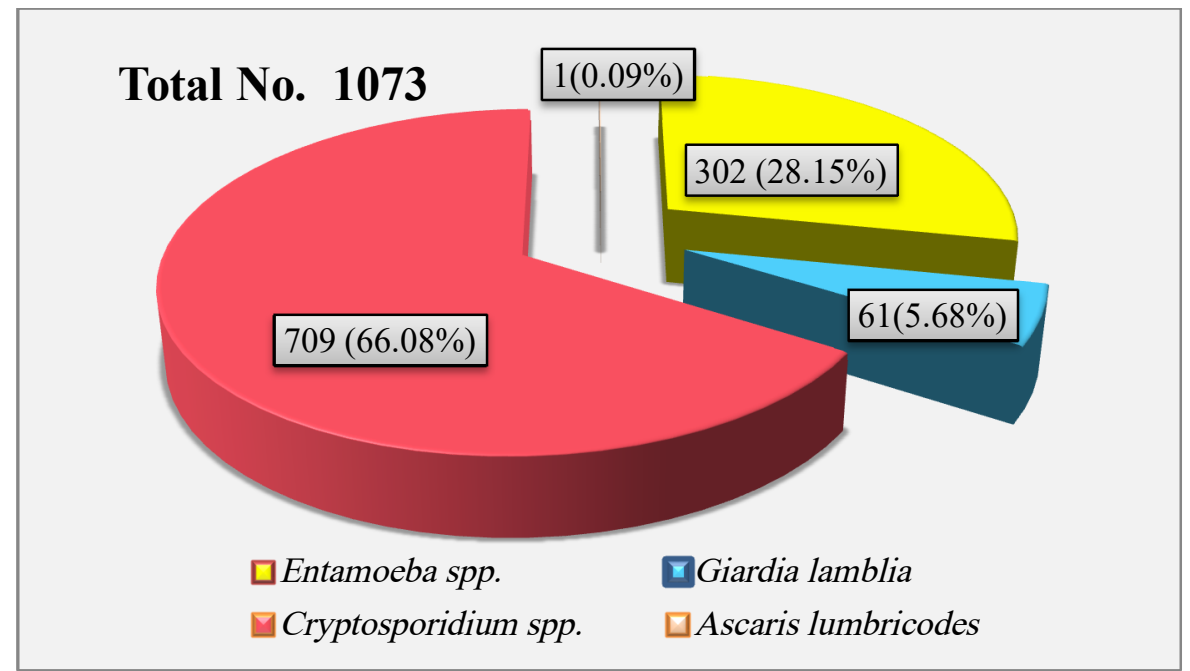

Fig. 2: Distribution of different intestinal parasites among the total examined children in Duhok city.

Environmental Variables and water Supply for IPIs

Potential seasonal fluctuations were evaluated to determine the possible impact of parasitic infections at different seasons during the study period. The highest rate of infection was seen in autumn (fall) season
$494(56.85 \%)$, while the lowest rate of infection was seen in spring season 58 (6.67\%), as shown in Table (3). There was a highly significant difference between seasons $(p<0.001)$.

Table 3: Distribution of Intestinal Parasitic Infections among the Total Examined Children According to (Seasons) in Duhok City

\begin{tabular}{lclcc}
\hline Seasons & $\begin{array}{c}\text { No. of } \\
\text { Examined }\end{array}$ & $\begin{array}{c}\text { No. (\%) of } \\
\text { Positive Stool }\end{array}$ & $\begin{array}{c}\text { No. (\%) of } \\
\text { Negative Stool }\end{array}$ & $\begin{array}{c}\text { (\%) of Infection among } \\
\text { Total Children }\end{array}$ \\
\hline Autumn & 862 & $494(57.31 \%)$ & $368(42.69 \%)$ & 56.85 \\
Winter & 214 & $96(44.86 \%)$ & $118(55.14 \%)$ & 11.05 \\
Spring & 124 & $58(46.77 \%)$ & $66(53.23 \%)$ & 6.67 \\
Summer & 348 & $221(63.51 \%)$ & $127(36.49 \%)$ & 25.43 \\
\hline Total & $\mathbf{1 5 4 8}$ & $\mathbf{8 6 9 ( 5 6 . 1 4 \% )}$ & $\mathbf{6 7 9 ( 4 3 . 8 6 \% )}$ & $\mathbf{1 0 0}$ \\
\hline
\end{tabular}

$\chi 2=23.622$, D.F $=3, p<0.001 * * *$

*** Highly Significant Difference.

Children of the artificial milk type feeding group showed the highest infection rate of 547 (62.95\%), while children of the breastfeeding group showed the lowest infection rate $58(6.67 \%)$. The rate of infection varied in different types of feeding groups. There was a highly significant difference between the groups $(p<0.001)$, as shown in table (4). 
Table 4: Distribution of intestinal parasitic infections among the total examined children according to (feeding-groups) in Duhok City

\begin{tabular}{llccc}
\hline Feeding-Groups & $\begin{array}{c}\text { No. of } \\
\text { Examined }\end{array}$ & $\begin{array}{c}\text { No. (\%) of } \\
\text { Positive Stool }\end{array}$ & $\begin{array}{c}\text { No. (\%) of } \\
\text { Negative Stool }\end{array}$ & $\begin{array}{c}\text { (\%) of Infection } \\
\text { Among Total } \\
\text { Children }\end{array}$ \\
\hline Breast milk feeders & 238 & $58(24.37 \%)$ & $180(75.63 \%)$ & 6.67 \\
Artificial milk feeders & 808 & $547(67.70 \%)$ & $261(32.30 \%)$ & 62.95 \\
Both type feeders & 181 & $62(34.25 \%)$ & $119(65.75 \%)$ & 7.13 \\
Non-milk feeders & 321 & $202(62.93 \%)$ & $119(37.07 \%)$ & 23.25 \\
\hline Total & $\mathbf{1 5 4 8}$ & $\mathbf{8 6 9 ( 5 6 . 1 4 \% )}$ & $\mathbf{6 7 9 ( 4 3 . 8 6 \% )}$ & $\mathbf{1 0 0}$ \\
\hline
\end{tabular}

$\chi 2=182.612$, D.F $=3, p<0.001 * * *$

*** Highly Significant Difference.

The distributions of intestinal parasitic infections according to children residential area. The highest infection rate was seen in children residing in camps 306 (35.21\%), followed by children living in the villages
208 (23.94\%). The lowest infection rate was seen in children living in the city center $319(18.30 \%)$. There was a highly significant difference between different groups $(p<0.001)$ as shown in table (5).

Table 5: Distribution of Intestinal Parasitic Infections among the Total Examined Children According to (Residential Area) in Duhok City

\begin{tabular}{llccc}
\hline Residential Area & $\begin{array}{c}\text { No. of } \\
\text { Examined }\end{array}$ & $\begin{array}{c}\text { No. (\%) of } \\
\text { Positive Stool }\end{array}$ & $\begin{array}{c}\text { No. (\%) of } \\
\text { Negative Stool }\end{array}$ & $\begin{array}{c}\text { (\%) of Infection } \\
\text { among Total Children }\end{array}$ \\
\hline Centre of the City & 319 & $159(49.84 \%)$ & $267(57.67 \%)$ & 18.30 \\
District & 463 & $196(42.33 \%)$ & $160(50.16 \%)$ & 22.55 \\
Villages & 380 & $208(54.74 \%)$ & $172(45.26 \%)$ & 23.94 \\
Camps & 386 & $306(79.27 \%)$ & $80(20.73 \%)$ & 35.21 \\
\hline Total & $\mathbf{1 5 4 8}$ & $\mathbf{8 6 9}(\mathbf{5 6 . 1 4 \% )}$ & $\mathbf{6 7 9}(\mathbf{4 3 . 8 6 \% )}$ & $\mathbf{1 0 0}$ \\
\hline
\end{tabular}

$\chi 2=125.2$, D.F $=3, p<0.001 * * *$

*** Highly Significant Difference.

The distribution of intestinal parasitic infections (IPIs) according to the source of water, the highest rate of infection was shown in tap water (river, well, or rain) $489(56.27 \%)$, and the lowest rate of infection was demonstrated in filtered water 119(13.69\%). There was a highly significant difference among different sources $(p<0.001)$, as shown in table (6). 


\begin{tabular}{|c|c|c|c|c|}
\hline \multicolumn{4}{|c|}{ Duhok Medical Journal } & Volume 15, Issue 1, 2021 \\
\hline \multicolumn{5}{|c|}{$\begin{array}{l}\text { Table 6: Distribution of intestinal parasitic infections among the total examined children } \\
\text { according to (water source) in Duhok City }\end{array}$} \\
\hline $\begin{array}{l}\text { Source of } \\
\text { Water }\end{array}$ & $\begin{array}{c}\text { No. of } \\
\text { Examined }=\end{array}$ & $\begin{array}{c}\text { No. }(\%) \text { of } \\
\text { Positive Stool }\end{array}$ & $\begin{array}{c}\text { No. }(\%) \text { of } \\
\text { Negative Stool }\end{array}$ & $\begin{array}{c}\text { (\%) of Infection among } \\
\text { Total Children }\end{array}$ \\
\hline Tap water & 896 & $489(54.58 \%)$ & $407(45.42 \%)$ & 56.27 \\
\hline Filter water & 251 & $119(47.41 \%)$ & $132(52.59 \%)$ & 13.69 \\
\hline Both water & 401 & $261(65.09 \%)$ & $140(34.91 \%)$ & 30.03 \\
\hline Total & 1548 & $869(56.14 \%)$ & $679(43.86 \%)$ & 100 \\
\hline
\end{tabular}

$\chi 2=21.695$, D.F $=2, p<0.001 * * *$

*** Highly Significant Difference.

The distribution of intestinal parasite infection according to clinical features, is shown in table (7). Intestinal parasitic infection were significantly related to cases presenting symptoms of diarrhea 334 (38.4\%). There was a highly significant difference between different groups at $(p<0.001)$ level. The rates of other clinical features did not show significant variances between intestine parasite-infected and non-infected stool specimens.

Table (7): Distribution of Intestinal Parasitic Infections, among the Total Examined Children According to (Clinical Aspects) in Duhok City

\begin{tabular}{lllcc}
\hline Clinical Presentation & $\begin{array}{c}\text { No. of } \\
\text { Children with } \\
\text { the clinical } \\
\text { manifestation }\end{array}$ & $\begin{array}{c}\text { No. (\%) of } \\
\text { Children with } \\
\text { Positive Stool }\end{array}$ & $\begin{array}{c}\text { No. (\%) of } \\
\text { Children with } \\
\text { Negative Stool }\end{array}$ & $\begin{array}{c}\text { (\%) of Infection } \\
\text { Among Total } \\
\text { Children with } \\
\text { Positive Stool }\end{array}$ \\
\hline non bloody diarrhea & 492 & $334(67.89 \%)$ & $158(32.11 \%)$ & 38.43 \\
Fever & 85 & $33(1 \%)$ & $52(61.18 \%)$ & 3.80 \\
Vomiting & 32 & $13(35.23 \%)$ & $19(59.38 \%)$ & 1.50 \\
All (D., V.,\& F.,) & 453 & $289(63.8 \%)$ & $164(36.20 \%)$ & 33.26 \\
Abdominal pain & 88 & $31(33.82 \%)$ & $57(64.77 \%)$ & 3.57 \\
Bloody diarrhea & 131 & $73(40.63 \%)$ & $58(44.27 \%)$ & 8.40 \\
Constipation & 72 & $22(30.56 \%)$ & $50(69.44 \%)$ & 2.53 \\
Asymptomatic & 94 & $39(41.49 \%)$ & $55(58.51 \%)$ & 4.49 \\
Others & 101 & $35(34.65 \%)$ & $66(65.35 \%)$ & 4.03 \\
\hline Total & $\mathbf{1 5 4 8}$ & $\mathbf{8 6 9 ( 5 6 . 1 4 \% )}$ & $\mathbf{6 7 9}(\mathbf{4 3 . 8 6 \% )}$ & $\mathbf{1 0 0}$ \\
\hline
\end{tabular}

$\chi 2=113.743$, D.F $=8, p<0.001 * * *$

*** Highly Significant Difference.

\#D.= Diarrhea, $\mathrm{V} .=$ Vomiting, and F. $=$ Fever

\section{DISCUSSION}

Intestinal parasitic infection are still presenting a hazardous public health problem among children in Duhok city. Studying the prevalence of infection among children in different regions of the country and associated risk factors is 
necessary to recognize high-risk groups and design proper control measures.

In this present study, the overall prevalence of IPIs was high $(56.14 \%)$ because many variables were affecting and increasing the rate of infections, such as lower socio-economic status, poor living conditions, residence, living in large size household, insufficient source of drinking water, large numbers of non-breast feeders, and low personal sanitation of children.

In the present study, the high rate of infection was in agreement with other studies in different regions of the world, for instance, in Argentina ${ }^{16}$. The prevalence also revealed an agreement with other studies in Iraq, e.g., in Baghdad $^{17}$. At the same time, our results contrast with other previous studies in other countries, e.g., in $\operatorname{Iran}^{18}$ and in Egypt $^{19}$.

This study showed that the intestinal protozoan infection (56.04\%) was significantly higher than the intestinal helminthic incidence; Ascaris only one case of helminth species detected $(0.06 \%)$. Different reports presented Ascaris as the only most common intestinal worm among children; this likely may be attributable to the direct transmission of infection and the high resistance of the infective egg to unsuitable conditions in the region that prolong and supports illness ${ }^{20}$.

Our results disagree with Hussein and Meerkhan $^{21}$. Their results showed that the highest infection rate was with Entamoeba histolytica, followed by Giardia lamblia, Enterobius vermicularis, and Cryptosporidium spp. among samples that he affirmed to collect. However, their study mentioned that all the stool samples were examined by direct microscopic examination and formalin-ether concentration methods. These methods cannot detect Cryptosporidium spp. and Enterobius vermicularis easily as they claimed. Furthermore, they mentioned that their study (with a period of six months) depended on the data and samples collected from the Heevi Pediatric Hospital. However, they did not mention the necessary code for them nor the date of approval by the Duhok Health Directorate ethical committee. These are very essential for such a study considering the ethical issues involved. Therefore, our study presented here is the first documented and ethically approved one that reports the infection of the patients in Duhok children's hospital with intestinal parasites. The findings were close to a local study was led by Rhadi team in Basrah Province $^{22}$, which found intestinal protozoans were more than worms' infections, and in $\operatorname{Iran}^{23}$. The high prevalence of protozoan parasites could be due to protozoan's simple life stage that does not need an intermediate host. It could also be due to the easy transmission methods of infection, such as fecal-oral ways, either directly from person to person or indirectly by eating or drinking fecal contaminated food and water ${ }^{24}$. In contrast, a local study in Iraq by Ihsan team presented the rate of intestinal helminths infections was higher than other intestinal infections among children ${ }^{25}$, also a study in Rwanda ${ }^{26}$.

Socio-demographic, environmental, and hygienic factors were also studied in the present study; both gender, males and females, were exposed to the chance of intestinal parasite diseases; the highest rate 
of infections was found in boys than in girls. A similar study in Saudi Arabia presented a higher infection rate in males than females ${ }^{27}$. This could be due to males being more in interaction with environmental situations than females. Males are more exposed to unhygienic environments as they play with contaminated soil, play with pets on grounds, or swim in unhygienic water during outside activities. At the same time, females may stay inside the household.

The prevalence of intestinal parasitic diseases was noticeable in all age groups. In an agreement with a local study in Iraq, Kurdistan Region, in Erbil governorate ${ }^{28}$; the highest rate of infection was found in the age group of (1-5) years old, followed by the age group of less than one year, whereas a low infectivity rate was found in the age group of (5-12) years old. This may be explained that young children creep on the dirty ground. This group of children could be more included in outdoor activities, leading to intestinal parasite transmission. Indifference, a study in Mosul showed the highest infection rate within children aged more than 5 years ${ }^{29}$.

In the current study, the most significant risk factor of parasitic infections was feeding practice; children fed with artificial milk had a higher incidence rate of infections than breastfed children, this result in agreement with the study in Baghdad $^{17}$.

The rate of infections varied according to seasonal and environmental variations. The highest infection rate was found in the fall season, followed by the summer season, and the lowest rate of infection was found in winter and spring. There was a highly significant association between the season and the intensity of intestinal parasite infections. A study in Saudi Arabia, in Riyadh city, showed the highest rate of infections among patients were found in the fall season period ${ }^{30}$. This could be attributed to the variance within the tested number of patient's stool specimens. Also, the high rate of infection in the summer season, related to favorable weather conditions such as high temperature and humidity, affects the spread of intestinal parasites among children.

According to the source of drinking water, infection incidence was higher among children who drink tap water. This high prevalence may be associated with low water quality, broken-down sewage lines, and low chlorine levels. In an agreement, different reports from different countries have verified untreated water sources as the main risk cause of intestinal parasitic diseases ${ }^{16}$.

Cryptosporidium spp. was the most predominant intestinal protozoan infection detected by the modified acid-fast stain. In agreement with other studies, Cryptosporidium spp. is the most prevalent intestinal parasite, a local study conducted in Erbil $^{31}$. Also, reports from other countries were found similar findings in the United Arab Emirates ${ }^{32}$. This could be explained that the staining method Modified Zeihel-Neelsen, for coccidian intestinal parasites usually do not use and practice in laboratories; Modified ZeihelNeelsen Staining method, particularly among children with intestinal parasitic infections after concentration method, is necessary for this area.

Followed by, amoebiasis was one of the most prevalent intestinal protozoan 
diseases. Next, giardiasis was showed the lowest rate of infection compared to amebiasis; all age groups of both genders were disposed to both protozoa infections. The present study's finding is similar to local studies led in Al-Najaf ${ }^{33}$.

In concern with diarrhea symptoms, the present study showed similarity to a study done in $\operatorname{Iran}^{34}$, which found intestinal infections in diarrheic and non-diarrheic patients, but the infection prevalence was considerably higher in diarrheic patients. The intensity of infections was highly significantly associated with diarrhea and have presented different intestinal parasites as serious risk factors of diarrhea.

In this study, anemia was the most observed disease among children infected with intestinal parasite infections (the result note showing in the result section); this could be due to the effect of heavy existence of intestinal parasites and low nutritional level of a child. An agreement with a study done in Egypt ${ }^{35}$ presented the highest intestinal parasite infection rate with anemia in this region. In contrast to other countries, a study in Kenya ${ }^{36}$ found the highest rate of intestinal parasite infections among young children without anemia; this may be due to the identified parasite infections were probably in their early life development.

In the current study, while the prevalence rates of intestinal parasites were almost comparable with those of similar studies conducted in other regions of Iraq, the prevalence rates of infections are of public health significance. In the early detection of parasitic infection and successful treatment, early identification of some recorded clinical manifestations can help. Required health policies, health education, enhancement of socio-economic conditions, screening, and deworming of childhood intestinal parasites are recommended.

The study revealed that parasitic diseases are significant common health problems in Iraq, Kurdistan Region, especially in Duhok province. Therefore the infection controller processes and different strategies for planning active prevention programs are must be considered. In order to advance cleanliness and health education, improvement of awareness policies, particularly among young mothers with insufficient knowledge of intestinal parasite infections among children of different ages, is required. Also, other techniques for diagnosing intestinal parasite infections in the Hevii pediatric laboratory should be added to avoid the missing diagnosis of other parasite species.

\section{REFERENCES}

1. Efstratiou A, Ongerth JE, Karanis P . Waterborne transmission of protozoan parasites: Review of worldwide outbreaks - an update 2011-2016. Water Res. 2017; 114:14-2.

2. Faria CP, Zanini GM, Dias GS, da Silva S, de Freitas MB, Almendra R, et al. Geospatial distribution of intestinal parasitic infections in Rio de Janeiro (Brazil) and its association with social determinants. PL Neg Trop Dis.2017; 11(3):11.

3. Fuhrimann S, Winkler MS, Pham-Duc P, Trung DD, Schindler C, Utzinger J, et al. Intestinal parasite infections and associated risk factors in communities exposed to wastewater in urban and peri-urban transition zones in Hanoi, 
Vietnam. Parasites Vec. 2016; 9(1):537.

4. Campbell SJ, Nery SV, Este CAD, Gray DJ, McCarthy JS, Traub RJ, et al. Water, sanitation and hygiene related risk factors for soil-transmitted helminth and Giardia duodenalis infections in rural communities in Timor-Leste. Int J Parasitol. 2016; 46(12):771-9.

5. Al-Mekhlafi AM, Abdul-Ghani R, Mahdy MA. School-based prevalence of intestinal parasitic infections and associated risk factors in rural communities of Sana'a, Yemen. Act Trop Nov. 2016; 163: 135-1.

6. Raza HH \& Sami RA. Epidemiological study on gastrointestinal parasites among different sexes, occupations, and age groups in Sulaimani district. J Doh Uni. 2009; 12(1): 317-3.

7. Hassen AO, Ashankyty IM, Haouas NAS . Prevalence of intestinal parasite infections among patients in local public hospitals of Hail, Northwestern Saudi Arabia. Asia Pac J Trop Med.2016; 9(1):44-8.

8. Haghighi A, Riahi SM, Taghipour A, Spotin A, Javanian M, Mohammadi $\mathrm{M}$, et al. Amoebiasis in Iran: a systematic review and meta-analysis. Epidemiol Inf. 2018; 146(15):188090.

9. Nwalorzie C, Onyenakazi SC, Ogwu SO, Okafor AN. Predictors of intestinal helminthic infections among school children, Nigeria. Nig J Med. 2015; 24(3):233-1.

10. Salman AO, Mhaisen FT, Al-Tae AA. On the occurrence of some intestinal parasites among diarrheic children attending a hospital in Al-Karkh side, Baghdad City, Iraq. Bio App Env Res. 2019; 3(2):93-2.

11. International Organization for Migration. Duhok Governorate Profile. Dahuk: IOM-Iraq. P. 16.2015 .

12. Daniel WW. Biostatistics: A Foundation for Analysis in the Health Sciences. $7^{\text {th }}$ ed. New York, John Wiley \& Sons: 1999.

13. Al-Saeed AT, Issa SH. Frequency of Giardia lamblia among children in Dohuk, northern Iraq. East Med Health J. 2006; 12(5): 555-1.

14. Al-Saeed AT, Issa SH. Detection of Giardia lamblia antigen in stool specimens using enzyme-linked immunosorbent assay. East Med Health J. 2010; 16(4):362-4.

15. Kumari B, Dutta H, Kalyani M . A Comparative Study on the Detection of Intestinal Parasites by Using Different Methods from Stool Sample in a Tertiary Care Centre. Int J Curr Microbiol App Sci. 2018; 7(04): 22193.

16. Cociancic P, Torrusio SE, Zonta ML, Navone GT. Risk factors for intestinal parasitoses among children and youth of Buenos Aires, Argentina. One Heal. 2020; 9: 100116.

17. Shakir MJ, Hussein AA. Frequency of intestinal parasitic infection among children under 5 years of age in Baghdad province. Int $\mathrm{J}$ Adv Res. 2014; 2(8):332-7.

18. Daryani A, Hosseini-Teshnizi S, Hosseini SA, Ahmadpour E, Sarvi S, Amouei $\mathrm{A}$, et al . Intestinal parasitic infections in Iranian preschool and school children: a systematic review 
and meta-analysis. Acta Trop. 2017; 169:69-3.

19. Monib M. Prevalence of intestinal parasites among children attending Assiut University Children's hospital, Assiut, Egypt. J Adv Parasitol. 2016; 3(4):125-1.

20. Oluwole AS, Adeniran AA, Mogaji HO, Olabinke DB, Abe EM, Bankole $\mathrm{SO}$, et al. Prevalence, intensity and spatial co-distribution of schistosomiasis and soil transmitted helminths infections in Ogun state, Nigeria. Parasitology Ope. 2018; $4(8): 1-9$.

21. Hussein JN \& Meerkhan AA. The incidence of intestinal parasites among children in Hivi Pediatric Hospital, Duhok Iraq. Sci J Uni Zak. 2019; 7(1):1-4.

22. Rhadi HA, Abdul-Zahra A, AbdulJabar S. Prevalence of Intestinal Pathogenic Parasites in Basrah City, Iraq. Inter J Scie Res. 2019; 8(2):17480.

23. Bahrami F, Haghighi A, Zamini GH, Khadem-Erfan MB, Eznolla A. Prevalence and associated risk factors of intestinal parasitic infections in Kurdistan province, northwest Iran. Bah Cog Med. 2018; 5: 1503777.

24. Shahdoust S, Niyyati M, Haghighi A, Azargashb E, Khataminejad MR. Prevalence of intestinal parasites in referred individuals to the medical centers of Tonekabon city, Mazandaran province. Gastroenterol Hepatol Bed Ben. 2016; 9(1):75-9.

25. Ihsan MA, Harith SA, Hussain SA. The prevalence of some gastrointestinal nematodes and cestodes in Iraqis. Asi Biom. 2016; 10 (1):61-6.

26. Butera E, Mukabutera A, Nsereko E, Munyanshongore C, Rujeni N, Mwikarago IE, et al . Prevalence and risk factors of intestinal parasites among children under two years of age in a rural area of Rutsiro district, Rwanda - a cross- sectional study. Pan Afr Med J. 2019; 32:11.

27. Ismail KA . Prevalence of Intestinal Parasitic Infection among School Children in Taif. Insights Biomed. 2018; 3(2):10.

28. Kanabe LO, Darogha SNR. Epidemiology of Cryptosporidiosis among diarrheic children of Raparin Pediatric hospital, Erbil provinceKurdistan Region, Iraq. Ciha Uni Erb Sci J. 2017; 1(1).

29. Al-alousi TI, Mahmood OI . Detection of Cryptosporidium oocysts in calves and children in Mosul, Iraq. College of Veterinary Medicine. Tikrit University. 2012; 280-285.

30. Amer OSO, Al-Malki ES,Waly MI, AlAgeel A, Lubbad MY et al. Prevalence of Intestinal Parasitic Infections among patients of King Fahd Medical City in Riyadh Region, Saudi Arabia: A 5- Year Retrospective Study. J Par Res. 2018; 8076274(4): 8.

31. Koyee QM, Faraj AM. Prevalence of Cryptosporidium spp. with other Intestinal Microorganisms among Regular Visitor of Raparin Pediatric Hospital in Erbil City-Kurdistan Region, Iraq. Zan J Pur Appl Sci. 2015; 27(4):574.

32. Al-Rifai RH, Loney T, Sheek-Hussein M, Zoughbor S, Ajab S, Olanda M, et al. prevalence of, and Factors 
Associated with Intestinal Parasites in Multinational Expatriate Workers in Al Ain City, United Arab Emirates: An Occupational Cross-Sectional Study. J Immi Min Heal. 2020; 22:359-4.

33. Ghazzay MH, Kiad SJ, Shamran SJ, Abdulbary M. Prevalence of amoebic dysentery and giardiasis in Al-Najaf. Int J Res Pharm Sci. 2018; 10(4):2960-4.

34. Kiani H, Haghighi A, Salehi R, Azargashb E. Distribution and risk factors associated with intestinal parasite infections among children with gastrointestinal disorders. Gastro Hep Bed Ben. 2016; 9(1):80-7.
35. Bayoumy AMS, El Raheem MAA, Abo Hashim AH, Al Saadawy ASK, Al Karyony IMR. Parasitic Profile Primary School Children in Rural Area at Beheira Governorate, Egypt. Egy J Hos Med. 2018; 70(12): 2042-9.

36. Koukounari A, Estambale BBA, Njagi JK, Cundill B, Ajanga A, Crudder C, et al. Relationship between anaemia and parasitic infections in Kenyan schoolchildren: A bayesian hierarchical modeling approach. Int J Parasitol. 2008; 38(14): 1663-1. 


\section{بوخته}

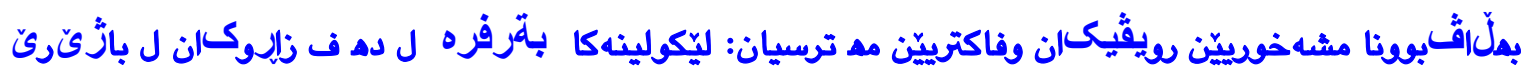

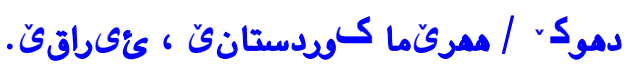

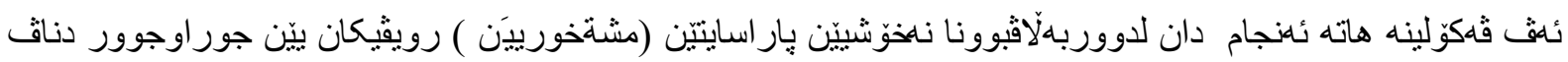

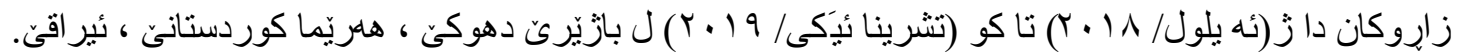

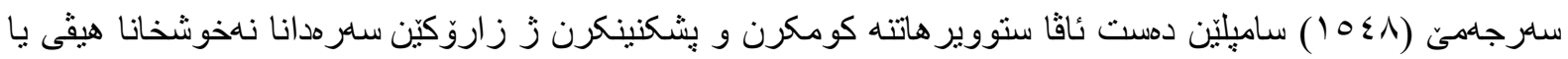

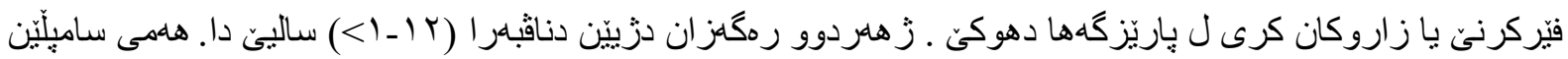

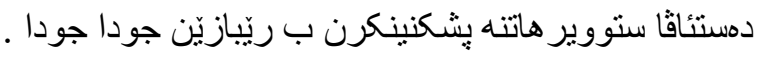

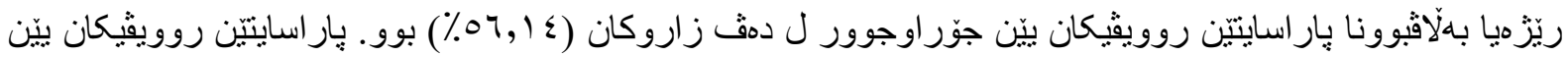

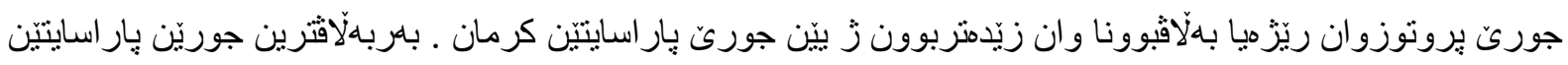

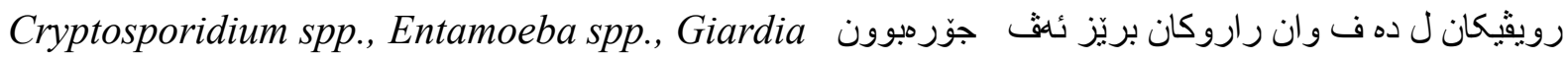
.lamblia, Ascaris lumbricoides

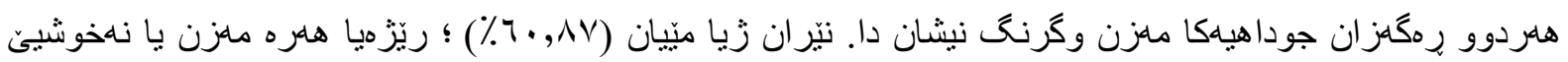

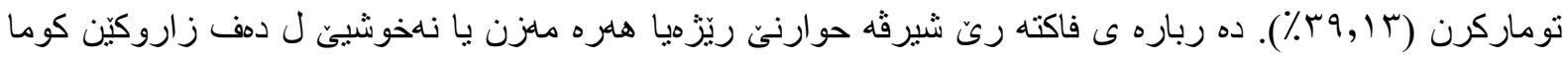

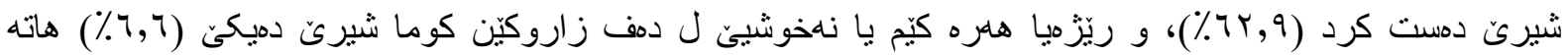
تو ماركرن .

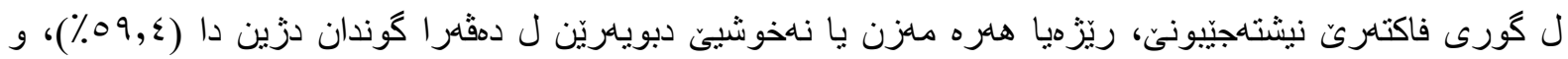

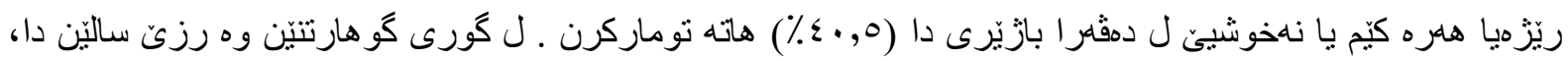

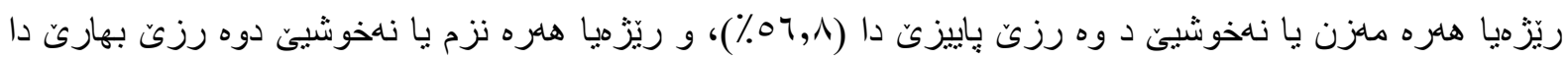

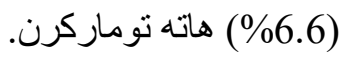

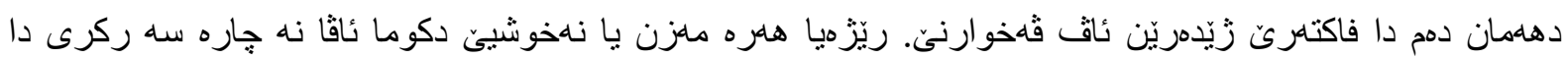

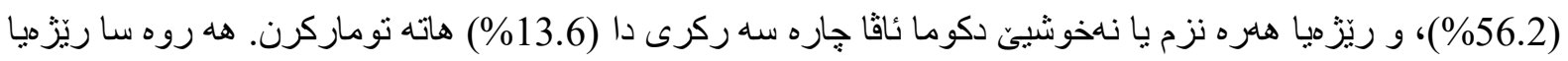

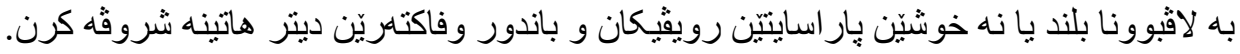




\section{الخلاصة}

انتشار الطفيليات المعوية وعوامل الخطر: مستح شامل بين الأطفال في مدينة دهوك ، إقليم كردستان العرلق

أجريت هذه الدراسة للتحري عن انتشار عدوى الطفيليات المعوية بين الأطفال خلال فترة (ايلول/ ^1 • ب) ولغاية (نهاية شهر تشرين الاول/ 9 ( • ب) في مدينة دهوك، إقليم كوردستان، العراق.

تم فحص (1^؛ 1) نموذجا من عينات البراز التي جمعت من الأطفال في مستثفى هيفي التعليمي للأطفال في محافظة

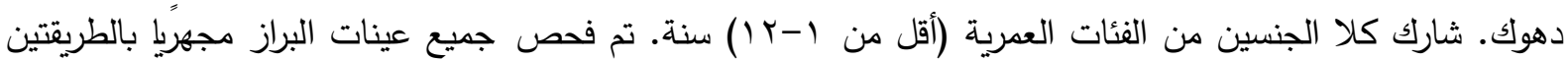

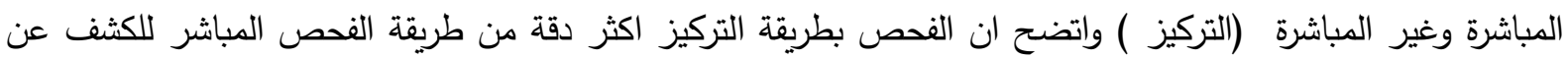
عدوى الطفيليات المعوية. وتم استخدام طريقة صبغة زييل-نيلسن المعدلة للكثف عن اكياس البيضية لطفيليات الأمعاء الكروية (داء خفيات الابواغ).

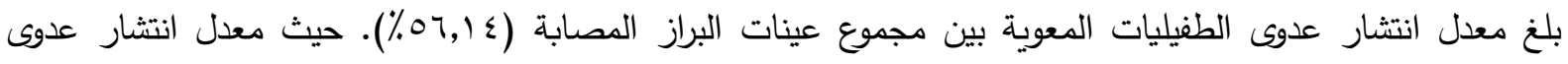

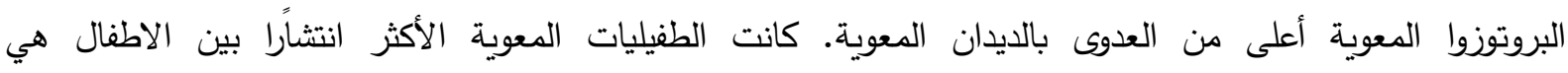
Giardia lamblia Entamoeba spp. Cryptosporidium spp.

.Ascari lumbricoides

لوحظ وجود فروقات احصائية معنوية بين الاصابات في الذكور والإناث (P>0.01)؛ سجلت أعلى نسبة اصابة

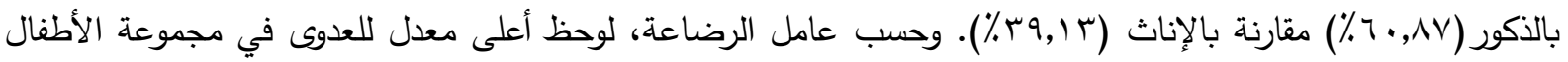

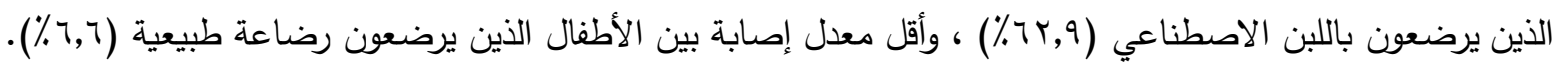
وبحسب عامل الإقامة، فإن أعلى نسبة إصابة سجلت بين الحالات التي تعيش في الريف (ء,هـ٪)، وأقل نسبة إصابة في الحالات التي تعيش في المدينة (ه,. ـ ٪). وحسب فصول السنة المختلفة، حيث سجلت أعلى نسبة إصابة في الخريف

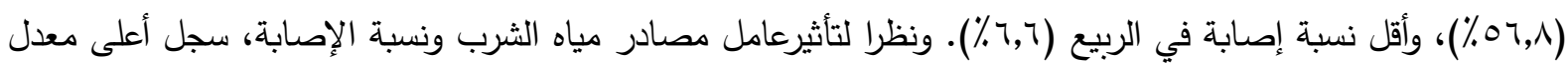

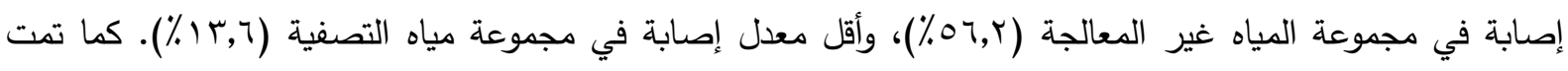
مناقشة تفاصيل معدل الانتشار المرتفع للعدوى بالطفيليات المعوية وتأثيرات بعض العضير العوامل الأخرى. 